Provided for non-commercial research and education use. Not for reproduction, distribution or commercial use.

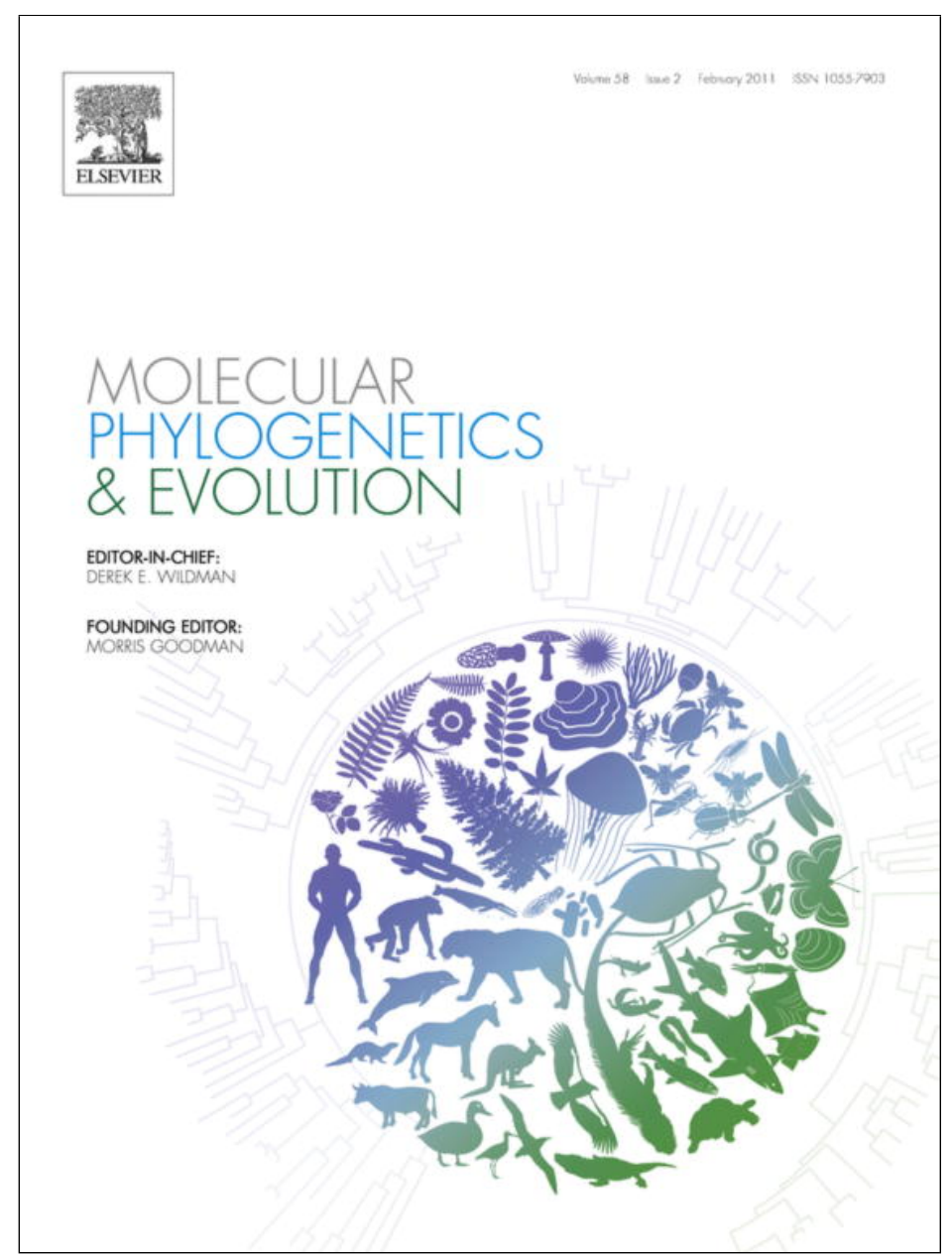

This article appeared in a journal published by Elsevier. The attached copy is furnished to the author for internal non-commercial research and education use, including for instruction at the authors institution and sharing with colleagues.

Other uses, including reproduction and distribution, or selling or licensing copies, or posting to personal, institutional or third party websites are prohibited.

In most cases authors are permitted to post their version of the article (e.g. in Word or Tex form) to their personal website or institutional repository. Authors requiring further information regarding Elsevier's archiving and manuscript policies are encouraged to visit:

http://www.elsevier.com/copyright 
Short Communication

\title{
Genetic architecture of the marbled goby Pomatoschistus marmoratus (Perciformes, Gobiidae) in the Mediterranean Sea
}

\author{
Randa Mejri ${ }^{a}$, Marco Arculeo ${ }^{b}$, Oum Kalthoum Ben Hassine ${ }^{a}$, Sabrina Lo Brutto ${ }^{\mathrm{b}, *}$ \\ a Unité de Recherche de Biologie, Ecologie et Parasitologie des Organismes Aquatiques, Département de Biologie, Tunis El Manar 2092, Tunisia \\ b Dipartimento di Biologia Animale "G. Reverberi", Università di Palermo, via Archirafi 18, Palermo 90123, Italy
}

\section{A R T I C L E I N F O}

\section{Article history:}

Received 3 June 2010

Revised 26 November 2010

Accepted 3 December 2010

Available online 15 December 2010

\section{Keywords:}

Pomatoschistus marmoratus

mtDNA

Phylogeography

Siculo-Tunisian strait

Adriatic Sea

Aegean Sea

Lagoon habitat

\begin{abstract}
A B S T R A C T
The marbled goby Pomatoschistus marmoratus, a species inhabiting coastal Mediterranean lagoons, has been studied by measuring its mitochondrial DNA variation. This analysis revealed a Mediterranean west $v s$ east split and, subsequently, an eastern differentiation among the Libyan-Tunisian Gulf, the Adriatic Sea and the Aegean Sea. The high cohesion between the samples collected in the vast area of western Mediterranean contrasts with the genetic mosaic of the more sub-structured eastern Mediterranean. This western homogeneity can not yet be fully explained even if a human-mediated migratory flow, due to a maritime traffic, has been posited. The pattern in the eastern basin revealed a genetic architecture possibly due to the non-migratory habit of the gobid. Within this perspective, the role of the Mediterranean lagoon habitat should be related to how much it amplifies the effects of historical (e.g. past sea-level changes) and environmental (e.g. present-day hydrographic regime) processes as regards the genetic structure of the inhabiting species.
\end{abstract}

(c) 2010 Elsevier Inc. All rights reserved.

\section{Introduction}

The semi-enclosed Mediterranean Sea is characterized by a peculiar physiography which, due to the presence of the three main north-south Iberian, Italian and Balkan peninsulas, subdivides the basin into different marine provinces or sub-basins. These are characterized by different hydrographic and ecological features, and are variously interconnected (Quignard, 1978; Bianchi and Morri, 2000; Agostini and Bakun, 2002). Such features render several marine species inhabiting the Mediterranean Sea of particular interest, since their genetic structure has been demonstrated to have been shaped by the combined effects of historical events and the complex interactions of ecological factors (Grant, 2005; Domingues et al., 2005; Lemaire et al., 2005; Zitari-Chatti et al., 2009; Riccioni et al., 2010).

Recent studies focusing on the Mediterranean Sea have assumed particular relevance due to its long evolutionary history throughout the Tertiary period, which is generally accepted to have greatly influenced the contemporary genetic structure of many species (Borsa et al., 1997; Avise, 2000; Grant, 2005; Patarnello et al., 2007; Pérez-Losada et al., 2007; Sirna-Terranova et al., 2006). Changes in climate and subsequent changes in sea level

\footnotetext{
* Corresponding author. Fax: +39 9123891855

E-mail address: sabrilob@unipa.it (S.Lo. Brutto).
}

have probably had diverse effects on different species, resulting in shifts in range as different geographical areas have become more or less suitable as a habitat, or isolating populations when barriers to dispersal arise.

The impact of ice ages on the structuring of genetic populations has been so strong as to occasionally facilitate the identification of various cryptic and profoundly differentiated lineages (Stefanni and Thorley, 2003; Gysels et al., 2004; Patarnello et al., 2007; Pérez-Losada et al., 2007; Sirna-Terranova et al., 2006; Calvo et al., 2009). Excluding past geomorphological processes, the delineation of distinct intra-specific lineages in Mediterranean species has been explained as the result of the present-day physical barriers to gene flow (e.g. Borsa et al., 1997; Mejri et al., 2009).

Despite the generalised high dispersal potential, which is associated with low levels of differentiation in marine organisms (Grant and Bowen, 1998; Avise, 2000), an increasing amount of data has described complex genetic structures in several Mediterranean marine species, where the actual dispersal seems to be limited by the habitat, or biological and oceanographic conditions (Avise, 2000; Lemaire et al., 2005; Maggio et al., 2009). In general, Mediterranean genetic data have revealed a compounded combination of historical and ecological components, wherein historical (diachronic) processes have been masked or indeed magnified by environmental (synchronic) processes (such as oceanographic features), especially acting in concert and at the same breakpoint to gene flow. 
A few of the aforementioned phylogeographical studies have focused particularly on the Gobidae family, which is well distributed and diversified in the Mediterranean Sea. Indeed, some of the species have highlighted a restricted gene flow throughout the SiculoTunisian Strait (e.g. Pomatoschistus tortonesei, Mejri et al., 2009), while others have revealed a strong breakpoint at the frontier of the Adriatic Sea (e.g. Pomatoschistus minutus, Stefanni and Thorley, 2003; Gysels et al., 2004). It seems that the intra-specific diversification of gobies has produced remarkable data in terms of ecological and genetic features, thus enhancing the attractiveness of this taxon to phylogeographers (Stefanni and Thorley, 2003; Gysels et al., 2004; Huyse et al., 2004; Verdiell-Cubedo et al., 2007; Berrebi et al., 2009; Giovannotti et al., 2009; Mejri et al., 2009).

of the numerous gobiine species found in the Mediterranean area, the marbled goby Pomatoschistus marmoratus (Risso, 1810) is one of the most abundant benthic fishes, inhabiting the sandy shallows of various estuaries and costal lagoons (Fouda et al., 1993; Koutrakis et al., 2000; Malavasi et al., 2004; Verdiell-Cubedo et al., 2007; Berrebi et al., 2009). This goby is widespread throughout the eastern Atlantic, Mediterranean, Black and Azov seas and Suez Canal (Miller, 1986), and it has a small-body which reaches a maximum total length of $65 \mathrm{~mm}$ (Miller, 1986). It is a non-migratory, euryhaline species which spends its entire life in the lagoon and it can be found preferentially in deep salty lagoons with minimal fluctuations in salinity (Rigal et al., 2008). P. marmoratus exhibits benthic eggs (Miller, 1984) and males build nests under empty bivalve shells, covering them with sand (Mazzoldi and Rasotto, 2001; Mazzoldi et al., 2002). Adults are considered to be poor swimmers because the pelvic fins have been fused into a suction disc (Miller, 1986), thereby suggesting that most large-scale dispersal is likely to depend on the short pelagic larval stage. There is an ever increasing number of studies regarding the biology and genetics of P. marmoratus (Wallis and Beardmore, 1984a,b; Miller et al., 1994; Penzo et al., 1998; Arculeo et al., 1999; Huyse et al., 2004) even if the genetic structure of its populations is yet to be studied throughout the entirety of its wide distribution area.

This lagunar species lives in scattered areas in the Mediterranen Sea and this fragmented distribution is, therefore, of great interest in identifying the factors influencing genetic architecture, which can be topographically diverse. The identification of these factors is crucial to our understanding of the spatial scale on which micro-evolutionary processes can occur and to delineating the geographical boundaries of potential genetic units. In order to improve our understanding of the structuring and historical demography of $P$. marmoratus in the Mediterranean Sea, its phylogeography was inferred by using two gene sequences of mitochondrial (mt) DNA (16S-rDNA and COI).

\section{Materials and methods}

\subsection{Sampling and sequencing}

A total of 56 marbled gobies were sampled from eight Mediterranean sites. Three sites were located in the western Mediterranean (W-MED): the Thau lagoon, THAU; the Vaccarès lagoon, VAC, in southern France; and the Bizerta lagoon, BIZ in northern Tunisia. Five sites were located in the eastern Mediterranean (EMED), subdivided thus: two samples were taken from the Libyan-Tunisian Gulf (LTG), the Lella el Hadria lagoon, LH, and the El Biban lagoon, BIB, in southern Tunisia; two samples obtained from the Adriatic Sea (ADR), the Venice lagoon, VEN, in northern Italy and Soline Bay, SOL, in Croatia; and one sample came from the Aegean Sea (AEG), the Vassova lagoon, VAS, in Greece (Fig. 1; Table 1). The specimens were collected by the authors of this paper or donated by other researchers between 2007 and 2009. Specimens were kept in absolute ethanol until the removal of their tissues. Total DNA extraction was carried out using the Dneasy tissue Kit (QIAGEN). A fragment of the mitochondrial 16S ribosomal RNA gene (16S-rDNA) (approximately $501 \mathrm{bp}$ in length) was amplified with the universal primers H16 and L16 (Palumbi, 1996). A fragment of the Cytochrome Oxidase I gene (COI) (approximately $647 \mathrm{bp}$ in length), located in the mitochondrial genome was amplified using the FishF1 and FishF2 primers (Ward et al., 2005). Sequences were generated in an Abi Prism 3700 (Applied Biosystems) automated sequencer.

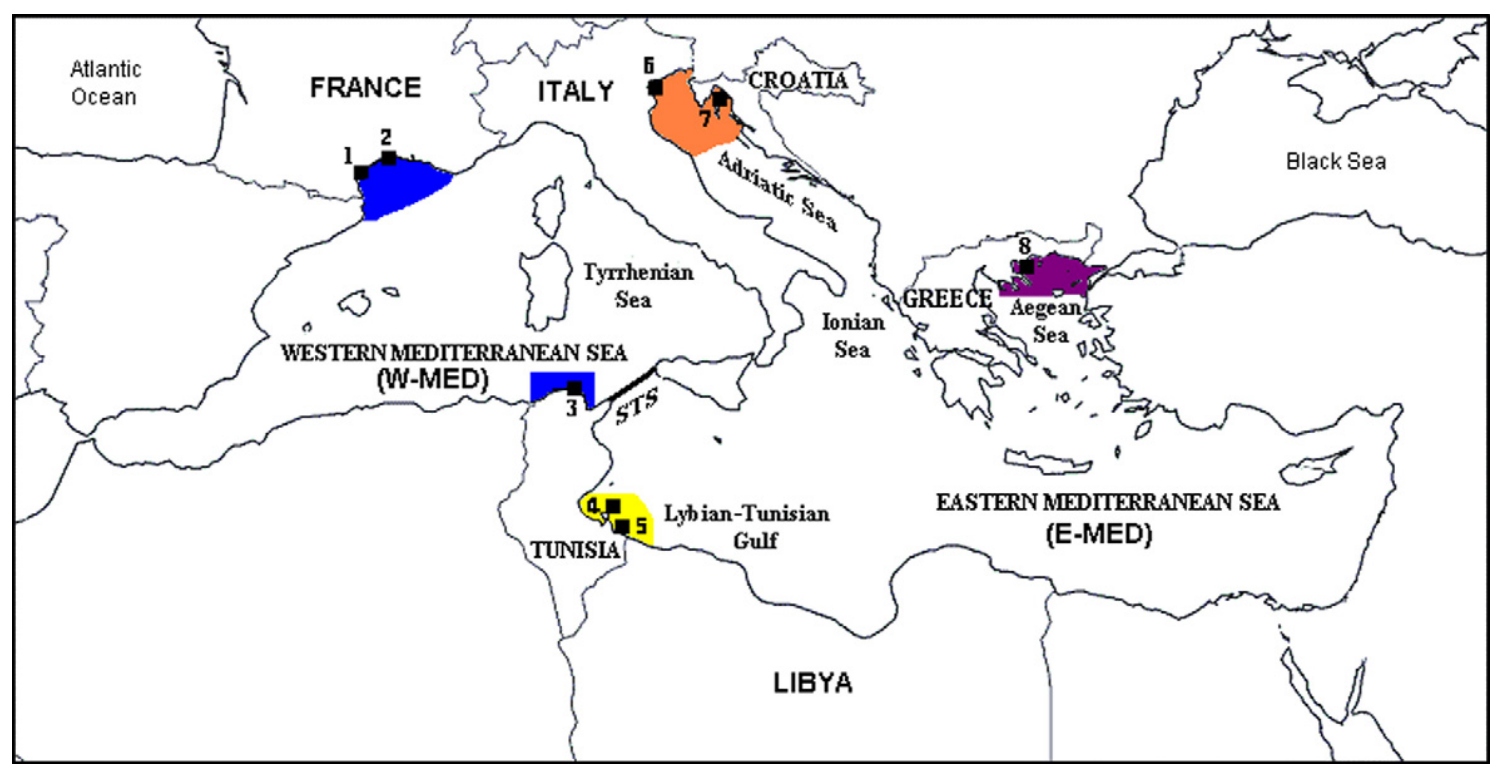

Fig. 1. Sampling sites of Pomatoschistus marmoratus. France: (1) Thau lagoon - THAU; (2) Vaccarès lagoon -VAC; Tunisia (3) Bizerta lagoon - BIZ; (4) Lella Hadria lagoon - LH; (5) El Bibane lagoon - BIB; Italy: (6) Venice lagoon - VEN; Croatia: (7) Soline Bay - SOL; Greece: (8) Kavala - KAV; Siculo-Tunisian Strait (STS); Libyan-Tunisian Gulf (LTG); Adriatic Sea (ADR); Aegean Sea (AEG). 
Table 1

Genetic diversity of the 16S-rDNA and COI sequences detected in Pomatoschistus marmoratus samples.

\begin{tabular}{|c|c|c|c|c|c|c|c|c|c|c|c|c|c|c|c|c|}
\hline \multirow[t]{3}{*}{ Locality } & \multirow{2}{*}{\multicolumn{6}{|c|}{ Western Mediterranean basin (W-MED) }} & \multicolumn{10}{|c|}{ Eastern Mediterranean basin (E-MED) } \\
\hline & & & & & & & \multicolumn{4}{|c|}{ Libyan-Tunisian Gulf (LTG) } & \multicolumn{4}{|c|}{ Adriatic Sea (ADR) } & \multicolumn{2}{|c|}{ Aegean Sea (AEG) } \\
\hline & THAU & & VAC & & BIZ & & LH & & BIB & & VEN & & SOL & & KAV & \\
\hline Loci & $16 S$ & $\mathrm{COI}$ & $16 \mathrm{~S}$ & $\mathrm{COI}$ & $16 S$ & $\mathrm{COI}$ & $16 S$ & $\mathrm{COI}$ & $16 \mathrm{~S}$ & $\mathrm{COI}$ & $16 S$ & $\mathrm{COI}$ & $16 S$ & $\mathrm{COI}$ & $16 S$ & $\mathrm{COI}$ \\
\hline$N$ & 8 & 8 & 5 & 5 & 3 & 3 & 8 & 8 & 10 & 10 & 5 & 5 & 5 & 5 & 12 & 12 \\
\hline$N_{h}$ & 1 & 4 & 2 & 2 & 2 & 2 & 6 & 8 & 2 & 5 & 3 & 2 & 4 & 2 & 7 & 8 \\
\hline$h$ & 0.000 & 0.643 & 0.400 & 0.400 & 0.667 & 0.667 & 0.893 & 1.000 & 0.200 & 0.756 & 0.700 & 0.400 & 0.900 & 0.600 & 0.833 & 0.848 \\
\hline$\pi$ & 0.000 & 0.001 & 0.001 & 0.001 & 0.003 & 0.002 & 0.003 & 0.004 & 0.001 & 0.002 & 0.002 & 0.001 & 0.006 & 0.005 & 0.003 & 0.005 \\
\hline
\end{tabular}

Sample size $(N)$; number of haplotypes $\left(N_{h}\right)$; nucleotide diversity $(\pi)$; haplotype diversity $(h)$.

\subsection{Genetic variability and population structure}

Sequencing results were manually edited with the BioEdit 7.0.5.3 program version (Hall, 1999) and the obtained sequences were aligned using the Clustal-W program (Thompson et al., 1994). Levels of mtDNA diversity were investigated by comparing population estimates of haplotype diversity $(h)$ and nucleotide diversity $(\pi)$, and both measures were computed using DnaSP v. 4.50 (Rozas et al., 2003) and Arlequin 3.11 (Excoffier et al., 2005) programs. The estimates of the gene flow $\left(F_{\mathrm{ST}}\right.$ and $\left.N_{e} m\right)$ (Hudson et al., 1992) were calculated by using the same software, and $p$ values were obtained by permutating data 1000 times.

Phylogenetic analyses were performed for each separate gene, using PAUP 4.0b10 (Swofford, 2002), and they considered both genes as concatenated. The trees were rooted with the $P$. tortonesei co-genus as an outgroup. A hierarchical series of likelihood ratio tests (Huelsenbeck and Rannala, 1997), implemented by the 0.1.1 jModelTest (Posada, 2008) and using the Akaike information criterion (Akaike, 1973), was applied in order to identify the appropriate nucleotide substitution model, with which to perform the maximum likelihood (ML) tree. Topological confidence was evaluated for all phylogenetic analyses, included Maximum Parsimony and Minimum Evolution, with 1000 bootstrap replicates (Felsenstein, 1985). The Minimum Spanning Network (MSN) method (Excoffier and Smouse, 1994), using SplitsTree version 4.10 (Huson and Byant, 2006), was further provided to graphically represent phylogenetic relationships among the haplotypes.

The samples belonging to the same sub-basin and clustered in a phylogenetic group were subsequently used for analyses by means of a hierarchical analysis of molecular variance AMOVA (Excoffier et al., 1992), using the software Arlequin version 3.11 (Excoffier et al., 2005). Four alternative groupings were tested with AMOVA to find the best fit for our data: I. Clustering samples together; II. Clustering the samples according to their separation in the two main Mediterranean basins: [W-MED] vs [E-MED]; III. Clustering the samples according to a finer structuring: [W-MED] vs [LTG] $v s$ [ADR] vs [AEG]; and IV. clustering only the samples from eastern Mediterranean: [LTG] vs [ADR] vs [AEG]. The grouping of sites which maximises $\Phi_{\mathrm{CT}}$ was assumed to be the most probable geographical subdivision. Significance was tested using a non-parametric permutation procedure (Excoffier et al., 1992), incorporating 10,000 permutations.

\subsection{Historical demography}

Demographic analyses were carried out separately for each of the clades detected in the ML and SAMOVA analyses. The historical demography of the different groups was examined using mismatch distribution analysis. This considers the distribution of pairwise differences between haplotypes (Rogers and Harpending, 1992) in order to evaluate possible events of population expansion or decline. The shape of a mismatch distribution is af- fected by historical demographical changes of the population: a sudden expansion after a bottleneck generates a uni-modal mismatch distribution and a star-shaped phylogeny, while stable or slowly declining populations do not produce a bell-shaped distribution (Slatkin and Hudson, 1991; Rogers and Harpending, 1992; Rogers, 1995).

The timing of expansion events was estimated by the relationships $\tau=2 u t$, where $t$ is the time since expansion in generations computed if the sudden expansion model was not rejected; $u$ is the mutation rate for the entire region; and $u=2 \mu k$, where $\mu$ is the per-nucleotide mutation rate and $k$ is the number of nucleotides in the sequence (Rogers and Harpending, 1992). We used the conventional rate equal to $2 \%$ per Myr, commonly applied for vertebrate mitochondrial mutation rate (Brown et al., 1979). Generation time for the studied species was 2 years (Miller, 1986).

The overall validity of the estimated demographic model was evaluated by the raggedness index ( $r g$ ) (Harpending, 1994) and the Ramos-Onsins and Rozas's $R_{2}$ (Ramos-Onsins and Rozas, 2002). Low raggedness values are typical of an expanding population whereas higher values are observed among stationary or bottlenecked populations (Harpending, 1994). Furthermore, the $R_{2}$ test, suitable for small sample sizes, is expected to produce lower values under a recent severe population growth scenario (RamosOnsins and Rozas, 2002). The significance of $r g$ and $R_{2}$ were assessed by parametric bootstraps (10,000 replicates), and the significant value was taken as evidence for a departure from the estimated demographic model of sudden population expansion. Tajima's $D$ (Tajima, 1989) and Fu's Fs (Fu, 1997) tests for mutation/drift equilibrium were performed in DnaSP 4.10 (Rozas et al., 2003) and Arlequin 3.11 (Excoffier et al., 2005) with 10,000 simulations.

\section{Results}

\subsection{Sequences}

A 501 and a $647 \mathrm{bp}$ fragment of the 16S-rDNA and the COI gene respectively were obtained for all the 56 specimens of $P$. marmoratus, which had been collected from the different sampling sites within the Mediterranean Sea. A total of 36 variable sites produced 23 haplotypes for 16S-rDNA; 17 haplotypes were unique and 22 nucleotide sites were parsimony informative. Fishes sharing the same $16 \mathrm{~S}$ haplotypes came from the same sampling site while those specimens originating from different sub-basins did not share identical haplotypes. The COI sequences revealed 29 haplotypes, produced by the 100 variables sites, of which 81 were parsimony informative; of these haplotypes, none was shared between the different areas under study. It is important to note that each sampling locality presented private haplotypes corresponding to unique haplotypes, which were found only in a single site (sensu Slatkin, 1985). The overall nucleotide diversity $(\pi)$ value for $16 S-$ 
rDNA sequences was $0.002 \pm 0.001$ and, within population $\pi$ values, it ranged from 0.0 to 0.006 . Values for haplotype diversity (h) varied from 0.0 to 0.9 and haplotype diversity averaged $0.887 \pm 0.028$ (Table 1 ). Values for nucleotide diversity $(\pi)$ for COI ranged from 0.001 to 0.005 for all the sampling sites and the nucleotide diversity averaged $\pi=0.003 \pm 0.001$. Values for haplotype diversity $(h)$ varied from 0.4 to 1.000 and haplotype diversity averaged $h=0.951 \pm 0.015$ (Table 1 ).

All populations displayed high values of haplotype diversity and low values for nucleotide diversity (Table 1 ). This combination has frequently been attributed to expansion after a period of low effective population size, with new mutations being retained (Grant and Bowen, 1998), and, in marine ecosystems, it can be related to the historical episodes of fluctuations in sea level.

\subsection{Phylogeographic inference}

Phylogenetic analyses performed on each of the two genes were, for the most part consistent, with $\mathrm{COI}$ thus providing a greater resolution among closely related populations. As demonstrated by analysing the 16S-rDNA + COI concatenated sequences, four phylogroups appeared as monophyletic with high bootstrap support values equal to $100 \%$ (Fig. 2).

On a larger geographical scale, the analysis revealed a phylogeographic divide between the western Mediterranean basin (WMED) vs the eastern Mediterranean basin (E-MED), involving three samples in the first phylogroup and five in the second. On a regional scale, three highly divergent phylogroups, with no geographical overlap and corresponding to different areas in the Mediterranean, were designated within the eastern Mediterranean basin (E-MED): i.e. the Libyan-Tunisian Gulf (LTG), the Adriatic Sea (ADR) and the Aegean Sea (AEG) (Fig. 2).

The population structure of $P$. marmoratus was also assessed by estimating the gene flow between the four main clusters (Table 2). The gene flow between the lineages and the two markers was found to be remarkably low with small numbers of migrants per generation $\left(N_{e} m\right.$ less than 0.03 ). All pairwise $F_{\mathrm{ST}}$ values between each Mediterranean region yielded very high and significant results (Table 2).
Table 2

Gene flow among Pomatoschistus marmoratus main clades, represented by $N_{e} m$ (above the diagonal) and F-statistics from haplotype frequencies (below the diagonal), calculated from 16S-rDNA + COI concatenated sequences.

\begin{tabular}{lllll}
\hline & W-MED & LTG & ADR & AEG \\
\hline W-MED & - & 0.01 & 0.02 & 0.02 \\
LTG & $0.16^{* *}$ & - & 0.02 & 0.02 \\
ADR & $0.15^{* *}$ & $0.06^{* *}$ & - & 0.06 \\
AEG & $0.13^{* *}$ & $0.03^{*}$ & $0.05^{*}$ & - \\
\hline
\end{tabular}

Significant $p$ values (based on 1000 permutations) are indicated by an asterisk $\left({ }^{*} 0.01<p<0.05 ;{ }^{* *} 0.001<p<0.01\right)$.

Western Mediterranean basin (W-MED), Libyan-Tunisian Gulf (LTG), Adriatic Sea (ADR) and Aegean Sea (AEG).

One gene pool test by AMOVA identified significant levels of genetic structure among the populations $\left(\Phi_{\mathrm{ST}}=0.95 ;{ }^{* * *} p<0.001\right)$, thereby indicating the existence of an heterogeneous structure with two or more groups of populations (Table 3 ). The grouping the [W-MED] + [E-MED] sequences explains a significant $\Phi_{\mathrm{CT}}$ value $\left(0.50,{ }^{*} 0.01<p<0.05\right)$ which is not the highest one. These two groups are clearly separated by a boundary falling precisely in the Siculo-Tunisian Strait (STS) (Fig. 1). The highest degree of discrimination occurred when populations were partitioned into four groups $-[\mathrm{W}-\mathrm{MED}]+[\mathrm{LTG}]+[\mathrm{ADR}]+[\mathrm{AEG}]-$ this splitting maximises $\Phi_{\mathrm{CT}}(0.95 ; 0.001<p<0.01)$ and explains $94.72 \%$ of the inter-sequence variation and is therefore a probable reflection of the underlying phylogeography (Table 3, Fig. 1).

\subsection{Patterns of historical demography}

Evolutionary relationships among haplotype sequences were also represented by the Minimum Spanning Network (MSN), based on the most parsimonious connection between two haplotypes (Fig. 3). This network supported the existence of the four lineages: W-MED, LTG, ADR and AEG in the Mediterranean Sea (Fig. 3). The network suggested that each geographical area maintains strong genetic cohesion in contrast with the marked divergence between each geographical area. Furthermore, the topologies of the sub-

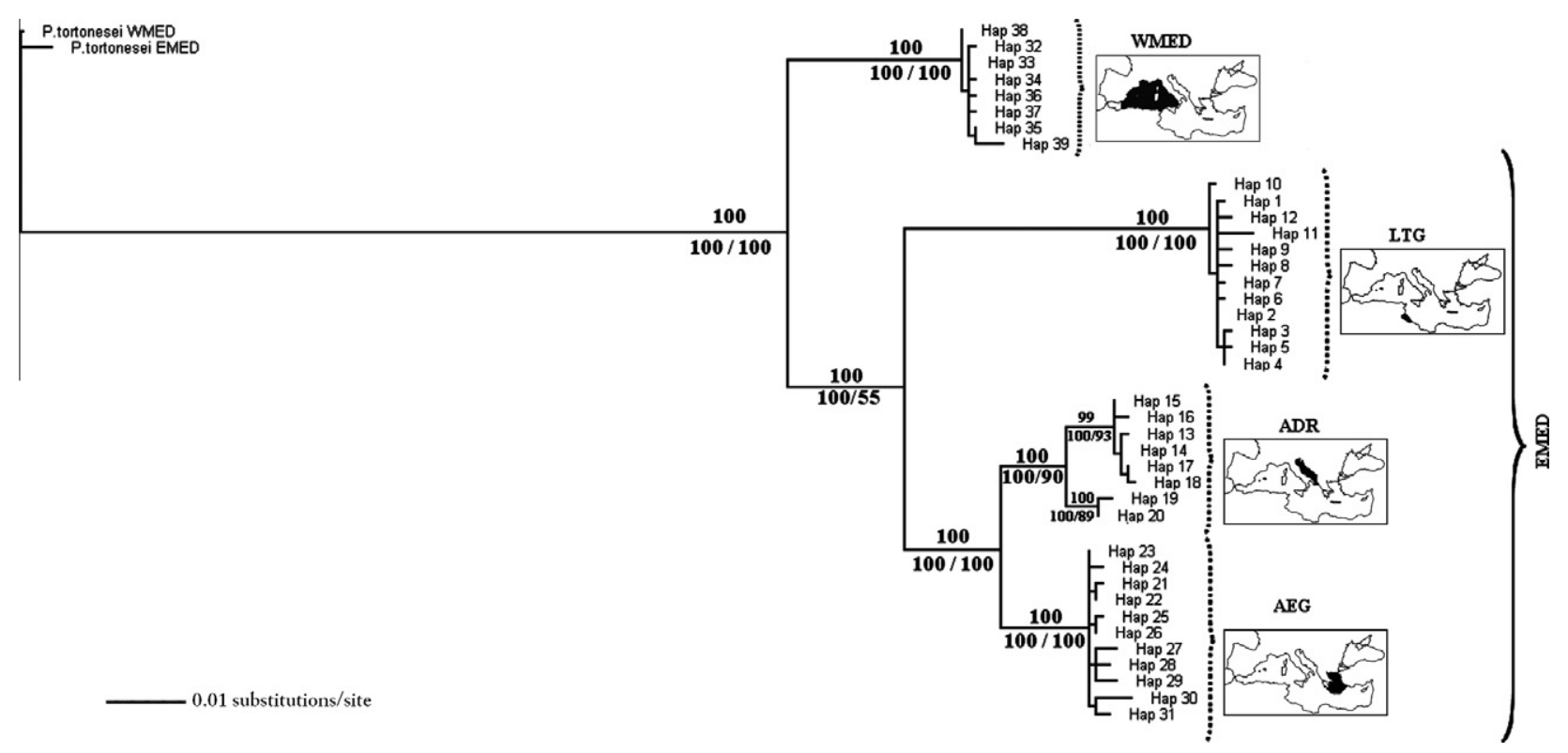

Fig. 2. Neighbour-joining tree constructed from TIM $2+\mathrm{G}$ model and based on 16S-rDNA + COI concatenated sequences of Pomatoschistus marmoratus using P. tortonesei, originating from the two Mediterranean basins, as outgroup. Numbers above branches reflect bootstrap values from maximum likelihood and below branches bootstrap values from Maximum Parsimony and Minimum Evolution, respectively. Western Mediterranean basin (W-MED), Libyan-Tunisian Gulf (LTG), Adriatic Sea (ADR), Aegean Sea (AEG) and Eastern Mediterranean basin (W-MED). 
Table 3

16S-rDNA + COI analysis of molecular variance (AMOVA), calculated from a distance matrix, with four grouping tested.

\begin{tabular}{|c|c|c|c|c|}
\hline Structure tested & Variance & $\%$ Total & $\Phi$-Statistics & $p$ \\
\hline \multicolumn{5}{|l|}{ I. All populations, one gene pool } \\
\hline Among populations & 23.85 & 94.53 & $\Phi_{\mathrm{ST}}=0.95$ & $* * *$ \\
\hline Within populations & 1.37 & 5.47 & & \\
\hline \multicolumn{5}{|c|}{ II. Western Mediterranean basin vs Eastern Mediterranean basin, [W-MED] vs [E-MED] } \\
\hline Among groups & 17.18 & 50.23 & $\Phi_{\mathrm{CT}}=0.50$ & $*$ \\
\hline Among populations within groups & 15.65 & 45.74 & $\Phi_{\mathrm{SC}}=0.92$ & $* * *$ \\
\hline Among populations & 1.38 & 4.03 & $\Phi_{\mathrm{ST}}=0.95$ & $* * *$ \\
\hline \multicolumn{5}{|c|}{ III. Western Mediterranean basin vs Libyan-Tunisian Gulf vs Adriatic Sea vs Aegean Sea, [W-MED] vs [LTG] vs [ADR] vs [AEG] } \\
\hline Among groups & 27.48 & 94.72 & $\Phi_{\mathrm{CT}}=0.95$ & $* * *$ \\
\hline Among populations within groups & 0.15 & 0.52 & $\Phi_{\mathrm{SC}}=0.10$ & ** \\
\hline Among populations & 1.37 & 4.76 & $\Phi_{\mathrm{ST}}=0.98$ & *** \\
\hline \multicolumn{5}{|c|}{ IV. Eastern Mediterranean basin: Libyan-Tunisian Gulf vs Adriatic Sea vs Aegean Sea, [LTG] vs [ADR] vs [AEG] } \\
\hline Among groups & 24.58 & 93.11 & $\Phi_{\mathrm{CT}}=0.93$ & $* * *$ \\
\hline Among populations within groups & 0.12 & 0.47 & $\Phi_{\mathrm{SC}}=0.06$ & * \\
\hline Among populations & 1.69 & 6.42 & $\Phi_{\mathrm{ST}}=0.94$ & $* * *$ \\
\hline
\end{tabular}

Significant $p$ values (based on 1000 permutations) are indicated by an asterisk $\left({ }^{*} 0.01<p<0.05 ;{ }^{* *} 0.001<p<0.01 ;{ }^{* * *} p<0.001\right)$.

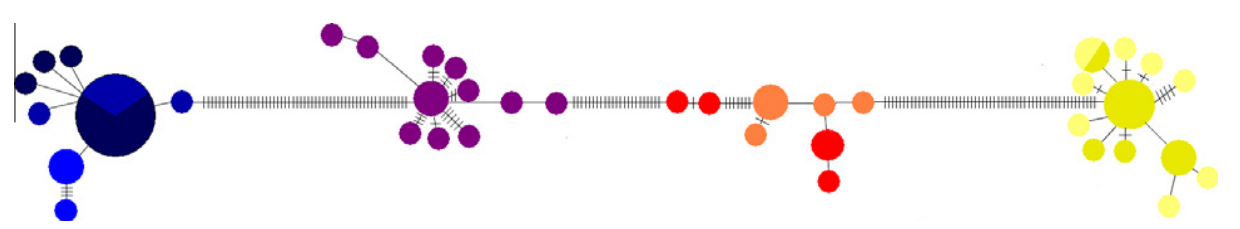

Fig. 3. Minimum Spanning Network (MSN) connecting all sequences through putative mutational step and separating the four major clades congruent with NJ tree subdivision: Western Mediterranean basin (W-MED, blue in the map) vs Libyan-Tunisian Gulf (LTG, yellow in the map) vs Adriatic Sea (ADR, orange in the map) vs Aegean Sea (AEG, purple in the map). The parsimony network was carried out using SplitsTree 4 showing relationships among all mitochondrial haplotypes found in 16S-rDNA + COI concatenated sequences of Pomatoschistus marmoratus. The circles represent haplotypes; circle diameters are proportional to the frequencies. Haplotypes (circles) are connected by the least number of pairwise substitutions; vertical bars on the line indicate the number of substitutions separating two haplotypes. Identification of samples: dark blue, Thau; blue, Vaccarès; light blue, Bizerta; light yellow, Lella Hadria; dark yellow, El Bibane; orange, Venice; red, Soline Bay; purple, Vassova. (For interpretation of the references to colour in this figure legend, the reader is referred to the web version of this article.)

networks were different: they varied from a pattern of a linear relationship connecting haplotypes, e.g. within the ADR clade, to a pattern where numerous rare haplotypes are connected to a central haplotype through single or few mutational steps. The latter resulted in a more or less well-defined star-like shape, as shown in the W-MED, LTG and AEG clade. In particular, the evidence of star-like phylogenies, suggesting past demographic expansions (Slatkin and Hudson, 1991), was in agreement with the mismatch analysis for the single LTG and AEG clades (Fig. 4), which revealed a single peak of pairwise differences among the sequences (Fig. 4). The model of sudden demographic expansion was not rejected by the Ramos-Onsins and Rozas $R_{2}$ test and the raggedness index $(r g)$. In addition, the values for Tajima's $D$ and Fu's Fs statistics (Fig. 4), which were significantly negative for these two clades, supposed the presence of selective forces or a population size expansion which occurred recently, as also indicated by the low levels of $\tau$ (Fig. 4). The estimates regarding timing since expansion ranged from 125,140 to 248,261 years before the present $\left(Y_{\mathrm{BP}}\right)$ for LTG and AEG respectively, assuming a generation time of two years.

An examination of the demographic histories of the western (W-MED) and the Adriatic (ADR) clades provided multimodal pairwise mismatch analyses, and the $R_{2}$ and $r g$ index were not significant (Fig. 4), as a result of constant population size. While the WMED clade produced significantly negative Tajima's $D$ and Fu's $F$ index, the ADR group revealed no significant tests of neutrality, thereby suggesting that this clade has remained stable for a period of time sufficient to reach an equilibrium via mutation or drift, thus rejecting the population expansion/bottleneck model.

Based on the results presented in this paper, it should be noted that the conclusions which can be drawn, and especially those coming from demographic analyses, should be taken with some caution because these rely on one locus only and the used marker is maternally inherited. From this point of view, it is desirable that further DNA markers with higher resolution will be used in order to reconstruct a more punctual phylogeography of this poorly studied gobid species.

\section{Discussion}

\subsection{West vs east mediterranean split}

The oldest genetic differentiation within the range of $P$. marmoratus coincides with the traditional bio-geographical partition in the western (W-MED) and eastern (E-MED) Mediterranean sub-basins (Bahri-Sfar et al., 2000; Bianchi and Morri, 2000), with the boundary between these two areas falling in the Siculo-Tunisian Strait (STS) (Fig. 1). The STS seems to form a barrier to gene flow since the pattern scored revealed a limited migrant exchange, also between the not distant populations sampled along the Tunisian coasts, i.e. between the sample from northern Tunisia, BIZ (W-MED), and the group of two samples from southern Tunisia, LH and BIB (E-MED) (Figs. 1-3). In contrast, the BIZ sample collected in northern Tunisia revealed a high degree of similarity with the French samples, THAU and VAC, which were located thousand kilometres apart in the northern western subbasin (Fig. 1).

The Siculo-Tunisian Strait (STS), from Cape Bon (Tunisia) to Mazara del Vallo (the island of Sicily, South Italy) has been inferred as a breakpoint between the two major Mediterranean western and eastern sub-basins, (Borsa et al., 1997; Astraldi et al., 1999; Bianchi and Morri, 2000). The bathymetry of this region is very complex and it exerts a strong influence on the water masses flowing through it, limiting the mixing of the water bodies on both 

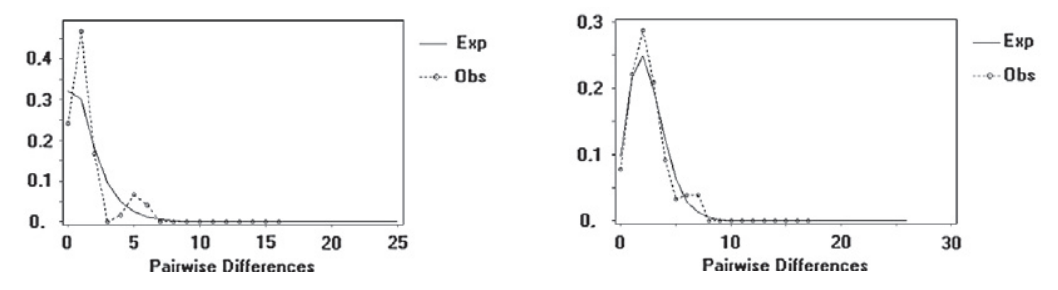

\begin{tabular}{ll}
\hline Clade & W-MED \\
\hline $\boldsymbol{N}$ & 16 \\
$\boldsymbol{\theta}_{\boldsymbol{0}}$ & 0.00000 \\
$\boldsymbol{\theta}_{\boldsymbol{l}}$ & 1000 \\
$\boldsymbol{\tau}$ & 1.16602 \\
$\boldsymbol{r g}$ & $0.17354^{\mathrm{NS}}$ \\
$\boldsymbol{R}_{\boldsymbol{2}}$ & $0.1011^{\mathrm{NS}}$ \\
$\boldsymbol{D}$ & $-1.93510^{* *}$ \\
$\boldsymbol{F} \boldsymbol{S}$ & $-4.11861^{* * *}$ \\
\hline
\end{tabular}

\begin{tabular}{ll}
\hline Clade & LTG \\
\hline $\boldsymbol{N}$ & 18 \\
$\boldsymbol{\theta}_{\boldsymbol{0}}$ & 0.00879 \\
$\boldsymbol{\theta}_{\boldsymbol{I}}$ & 1000 \\
$\boldsymbol{\tau}$ & 2.29883 \\
$\boldsymbol{r g}$ & $0.04998 *$ \\
$\boldsymbol{R}_{\boldsymbol{2}}$ & $0.0684 *$ \\
$\boldsymbol{D}$ & $-2.15031 * * *$ \\
$\boldsymbol{F} \boldsymbol{s}$ & $-7.18086 * * *$ \\
$\boldsymbol{t}$ & $125140 \mathrm{Y}_{\mathrm{BP}}$ \\
\hline
\end{tabular}
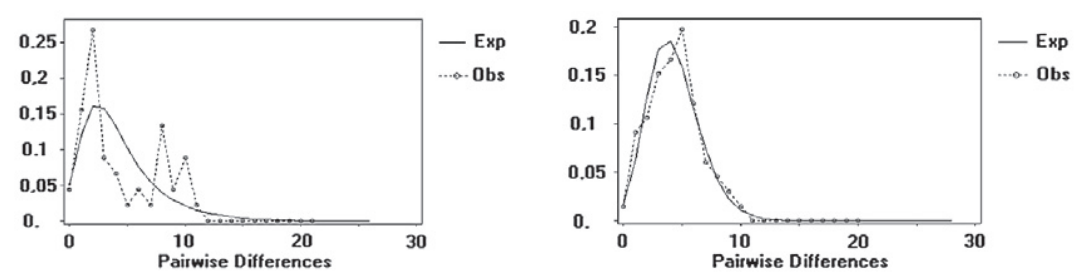

\begin{tabular}{ll}
\hline Clade & ADR \\
\hline $\boldsymbol{N}$ & 10 \\
$\boldsymbol{\theta}_{\boldsymbol{\theta}}$ & 3.29043 \\
$\boldsymbol{\theta}_{\boldsymbol{I}}$ & 1000 \\
$\boldsymbol{\tau}$ & 0.98438 \\
$\boldsymbol{r} \boldsymbol{g}$ & $0.08691^{\mathrm{NS}}$ \\
$\boldsymbol{R}_{\boldsymbol{2}}$ & $0.1264^{\mathrm{NS}}$ \\
$\boldsymbol{D}$ & $-0.54903^{\mathrm{NS}}$ \\
$\boldsymbol{F} \boldsymbol{S}$ & $-2.37683^{\mathrm{NS}}$ \\
\hline
\end{tabular}

\begin{tabular}{ll}
\hline Clade & AEG \\
\hline $\boldsymbol{N}$ & 12 \\
$\boldsymbol{\theta}_{\boldsymbol{0}}$ & 0.05078 \\
$\boldsymbol{\theta}_{\boldsymbol{I}}$ & 1000 \\
$\boldsymbol{\tau}$ & 4.56055 \\
$\boldsymbol{r} \boldsymbol{g}$ & $0.01951 *$ \\
$\boldsymbol{R}_{\boldsymbol{2}}$ & $0.0732 *$ \\
$\boldsymbol{D}$ & $-1.78198 * *$ \\
$\boldsymbol{F} \boldsymbol{s}$ & $-6.18855^{* * *}$ \\
$\boldsymbol{t}$ & $248261 \mathrm{Y}_{\mathrm{BP}}$ \\
\hline
\end{tabular}

Fig. 4. Mismatch distributions for $16 \mathrm{~S}$-rDNA + COI pairwise combinations of Pomatoschistus marmoratus sequences graphs associated to statistics detected from the demography analysis, observed (dashed line) pairwise mismatch distribution and expected (solid line) values in growing populations elaborated singularly for the four main clades: Western Mediterranean Sea (W-MED), Adriatic Sea (ADR), Libyan-Tunisian Gulf (LTG) and Aegean Sea (AEG). $X$ axis: pairwise differences; $Y$ axis: frequency; sample size $(N)$; theta initial $\left(\theta_{0}\right)$; theta final $\left(\theta_{1}\right)$; raggedness statistic $(r g)$; Ramos-Onsins and Rozas $R_{2}$ statistic $\left(R_{2}\right)$; Tajima's $D$ neutrality test $(D)$; Fu's test of neutrality $(F s)$ and time in generations $(t)$ after expansion expressed in years before present $\left(Y_{\mathrm{BP}}\right)\left({ }^{*} p<0.05 ;{ }^{* *} p<0.01 ;{ }^{* * *} p<0.005\right)$.

sides (Astraldi et al., 1999). Characterized by a series of 'quasi-permanent features', such as vortices and crests (Hamad et al., 2006), such a hydrographic regime bounds the natural dispersal across the STS. This, therefore, permits a progressive genetic differentiation within several species and exerts a strong influence on the mechanisms that counteract gene flow and promote structuring in the Mediterranean ecosystem (Bahri-Sfar et al., 2000; Perez-Losada et al., 2007).

The split into W-MED and E-MED P. marmoratus clades matches rather well that observed in the sand goby P. minutus (Stefanni \& Thorley 2003) and in the tortonese goby P. tortonesei (Mejri et al., 2009). Genetic analyses of these two gobiine species have revealed a population subdivision which has clearly demonstrated the action of the STS as breakpoint to gene flow within the Gobidae family. Such genetic differentiation has been also observed in several marine species like the flounder (Platichthys flesus; Borsa et al., 1997), the sea bass (Dicentrarchus labrax; Bahri-Sfar et al., 2000), the mackerel (Scomber japonicus, Zardoya et al., 2004), the bottlenose dolphins (Tursiops truncates; Natoli et al., 2005) and the car- mote prawn (Penaeus kerathurus, Zitari-Chatti et al., 2009). Given the different taxonomic groups involved and the different degree of differentiation within these species, the contribution of the STS extends to more than the mere function of a simple barrier promoting intra-specific genetic differentiation. It seems to play an important role in maintaining the different ecological characteristics of the western and eastern sub-basins, i.e. salinity, temperature, currents, primary production (Agostini and Bakun, 2002). For example, the western and eastern Mediterranean populations of the mammal T. truncates (Natoli et al., 2005) have been supposed to be isolated as a consequence of differences in habitat and consequently in the distribution of prey. Indeed, different feeding strategies maintain long-term individual associations across the generations (Natoli et al., 2005).

The STS represents a present-day hydrographical barrier as could have been the case in the past. Recurring shifts in sea level in the Mediterranean Sea during the Quaternary glaciations (Lambeck et al., 2002) repeatedly separated the two sub-basins, thereby bringing to the surface a land bridge at the Siculo-Tunisian sill; this 
has been demonstrated to have connected Sicilian and Tunisian terrestrial fauna (e.g. Stöck et al., 2008) but it reduced connectivity between the two marine provinces, W-MED and E-MED. Marine fauna was divided as a consequence of a typical vicariant mechanism, which caused an allopatric cladogenesis of new lineages.

Since lagoons constitute shallow ecosystems at marginal marine zonation, they could have been profoundly affected by the aforementioned fluctuations and much more so than in an opensea habitat. Fluctuations in sea level caused a reduction and/or disappearance of a suitable habitat, such as shallower lagoons, leading to extinction and habitat re-colonization, following the alternate cooling phases. Thus, the present-day gene pool of $P$. marmoratus is what remains after a process of multiple lineage sorting in the history of the species and this can explain why the clades display such pronounced differentiation.

\subsection{The eastern Mediterranean mosaic}

The high cohesion among the samples collected in the vast area of the western Mediterranean (W-MED) contrasts with the genetic 'mosaic' of the eastern Mediterranean (E-MED), which is more substructured. As the W-MED vs E-MED split has revealed a concordance with previous data, similarly, various studies have highlighted a genetic population structure in the eastern Mediterranean, with observed genetic breaks mainly in accordance with the regional sub-basins. Indeed, a few studies have maintained that the Libyan-Tunisian Gulf comprises a sub-basin within the E-MED (Bahri-Sfar et al., 2000), while others have demonstrated the isolation of the Adriatic populations (Guarniero et al., 2002; Arculeo et al., 2003; Stefanni and Thorley, 2003; Kristoffersen and Magoulas, 2008; Maggio et al., 2009). Still, further studies have demonstrated the presence of restricted gene flow from and towards the Aegean sub-basin (Magoulas et al., 1996; Bahri-Sfar et al., 2000; Nikula and Väinölä, 2003; Costagliola et al., 2004; Domingues et al., 2005; Pérez-Losada et al., 2007). The pattern highlighted in $P$. marmoratus coincides with all of these boundaries. Indeed, the genetic structure of the eastern marbled goby populations is consistent with the subdivision of the eastern Mediterranean into the following sub-basins: the Adriatic, ADR, the Aegean Sea, AEG, and the Libyan-Tunisian Gulf, LTG.

As P. marmoratus is strictly associated with lagoon habitats, which are transitional environments, and characterized by an instability of their physico-chemical parameters (Sarà, 2009), $P$. marmoratus could have been exposed to selective pressures more frequently than marine species inhabiting open-sea habitats. Such selective pressures could have acted to amplify pre-existent temporal heterogeneous genetic traits, as a result of historical and hydrographic mechanisms. The general idea that selective pressures in lagoons, and consequently strictly inhabiting species, and more so than in the open-sea, could play a greater role in shaping Mediterranean diversity merits further study.

According to Avise (2000), when co-distributed taxa display similar geographical patterns caused by a given historical event, the lineage separations in the gene tree tend to be deeper when the ancestral populations were already somehow structured. Thus, on the basis of the above assumption, the fact that the differentiation scored in the lagunar P. marmoratus is deeper than that found in other Mediterranean species inhabiting non-lagunar habitat should be highlighted. For instance, the differentiation of the sea star Astropecten aranciacus in the Mediterranean Sea is the result of an isolation-by-distance pattern, which allowed for any grouping to be significant. This occurs provided that geographical neighbours are clustered together and without there being a strong discrepancy between samples collected in the northern Adriatic and Aegean sub-basins (Zulliger et al., 2009). Many other examples derive from the population structure of Mediterranean pelagic spe- cies, which do not mirror palaeo-oceanographic events to such an extent. This has been demonstrated by: the European anchovy Engraulis encrasicolus (Grant, 2005; Grant et al., 2005; Magoulas et al., 2006), the Atlantic Bluefin tuna Thunnus thynnus (Riccioni et al., 2010), and the goby Aphia minuta (Giovannotti et al., 2009). And data from demersal species, such as the European hake Merluccius merluccius (Cimmaruta et al., 2005), or benthic species, e.g. the common sole Solea solea (Rolland et al., 2007) have produced similar results.

From an ecological point of view, lagoons are among the most important coastal marine ecosystems (Sarà, 2009). Their potential effects on the genetic structure of marine populations should thus be a major focus of interest. Their environmental marginality has great influence on the genetic structure of inhabiting populations, promoting diversity, in terms of distinctive populations. This is particularly relevant for the resident populations which have been isolated for long periods of time, as observed in the case of $P$. marmoratus. Consequently, much attention should be placed on the management and conservation of these vulnerable ecosystems and inhabiting species, particularly as they can be considered sources of cryptic genetic biodiversity.

Finally, it could be asked why, given the sedentary way of life of P. marmoratus, the genetic structure scored correlates so well with contemporary and historical factors only present in the eastern basin: one could expect that the single western lagoons are equally isolated from each other. On the contrary, samples from the WMED cluster robustly together and a simple local-scale differentiation has not been scored. Thus, an event could have prevented its isolation and guarantee an exchange of migrants across such great distances, such as that between Tunisia and France, that is, the distance between the BIZ (Bizerta) sample-site in northern Tunisia and the French sites, THAU (Thau lagoon) and VAC (Vaccarès lagoon), approximately one hundred kilometres from Marseilles.

Looking at the peculiarities of the western sites, the Bizerta lagoon reveals a connection with the open-sea represented by a channel where an active maritime harbour is located. As maritime transport has been recognized as the main cause of the marine invasion of non-indigenous species (Carlton and Geller, 1993; Miglietta and Lessios, 2009), it should also be considered responsible for the high gene flow between distant populations within a species range. The high potential of maritime transport as being a vector of migrants is due to the transport of ballast water, which is taken up and released in deep-water ports, and to the colonization of fouling communities on underwater machinery. The latter is the most probable way of transferring the benthic eggs of $P$. marmoratus. Whilst the port at Bizerta is not among the most active ports of the Mediterranean routeways, it was an important site during the Second World War. As an important French naval base, it belonged to the strategic triangle route of Marseilles-AlgeriaBizerta, which constitutes a permanent connection between Tunisia and France (Roucek, 1953). The hypothesis of human-mediated transport is possibly not so easy to demonstrate but it is gaining a foothold in contemporary literature as a non-secondary factor in explaining the genetic connectivity over long distances and across any kind of oceanographic barrier.

\section{Acknowledgments}

The authors of this Paper wish to thank those who kindly provided samples for this research (Pr. P. Berrebi, Dr M. Kovačic and Dr E. Koutrakis) and Dr Tiziana Curatolo for her technical assistance. The M.R. fellowship was supported by the Ministry of Education, Scientific Research and Technology of the Republic of Tunisia with research supported by the Università di Palermo (Fondi ex $60 \%$ ). The authors thank an anonymous reviewer for the very helpful suggestions. 


\section{References}

Agostini, V.N., Bakun, A., 2002. 'Ocean triads' in the Mediterranean Sea: physica mechanisms potentially structuring reproductive habitat suitability (with example application to European anchovy, Engraulis encrasicolus). Fisheries Oceanography 11 (3), 129-142.

Akaike, H., 1973. A new look at the statistical model identification. IEEE Transactions on Automatic Control 19, 716-723.

Arculeo, M., Mauro, A., Lo Brutto, S., Cammarata, M., Mazzola, A., Parrinello, N. 1999. Biochemical genetic differentiation between Pomatoschistus marmoratus and P. tortonesei. Journal of Fish Biology 54, 190-195.

Arculeo, M., Lo Brutto, S., Sirna-Terranova, M., Maggio, T., Cannizzaro, L., Parrinello, N., 2003. The stock genetic structure of two Sparidae species, Diplodus vulgaris and Lithognathus mormyrus, in the Mediterranean Sea. Fisheries Research 63 339-347.

Astraldi, M., Balopoulos, S., Candela, J., Font, J., Gacic, M., Gasparini, G.P., Manca, B., Theocharis, A., Tintore, J., 1999. The role of straits and channels in understanding the characteristics of Mediterranean circulation. Progress in Oceanography 44, 65-108.

Avise, J.C., 2000. Phylogeography: The History and Formation of Species. Harvard University Press.

Bahri-Sfar, L., Lemaire, C., Ben Hassine, O.K., Bonhomme, F., 2000. Fragmentation of sea bass populations in the western and eastern Mediterranean as revealed by microsatellite polymorphism. Proceedings of the Royal Society of London. Series B. 267, 929-935.

Berrebi, P., Rodriguez, P., Rooney, C., D’Aloya, S., Cattaneo-Berrebi, G., 2009. Haplotypic confinement in two cryptic and closely-related species of sedentary gobies, Pomatoschistus microps and $P$. marmoratus in French Mediterranean lagoons. Folia Zoologica 58 (1), 123-131.

Bianchi, N.C., Morri, C., 2000. Marine biodiversity of the Mediterranean Sea: situation, problems and prospects for future research. Marine Pollution Bulletin 40 (5), 367-376.

Borsa, P., Naciri, M., Bahri-Sfar, L., Chikhi, L., Garcia De Leon, F.J., Kotoulas, G., Bonhomme, F., 1997. Intraspecific zoogeography of the Mediterranean: population genetic analysis on sixteen Atlanto Mediterranean species (fish and invertebrates). Vie Milieu 47, 295-305

Brown, W.M., George, M., Wilson, A.C., 1979. Rapid evolution of animal mitochondrial DNA. Proceedings of the National Academy of Sciences, USA 76, 1967-1971

Calvo, M., Templado, J., Oliverio, M., Machordom, A., 2009. Hidden Mediterranean biodiversity: molecular evidence for a cryptic species complex within the reef building vermetid gastropod Dendropoma petraeum (Mollusca: Caenogastropoda). Biological Journal of the Linnean Society 96, 898-912.

Carlton, J.T., Geller, J.B., 1993. Ecological roulette: the global transport of nonindigenous marine organisms. Science $261,78-82$.

Cimmaruta, R., Bondanelli, P., Nascetti, G., 2005. Genetic structure and environmental heterogeneity in the European hake (Merluccius merluccius). Molecular Ecology 14, 2577-2591.

Costagliola, D., Robertson, D.R., Guidetti, P., Stefannin, S., Wirtz, P., Heise, J.B. Bernardi, G., 2004. Evolution of coral reef fish Thalassoma pavo spp. (Labridae). 2. Evolution of the eastern Atlantic species. Marine Biology 144, 377-383.

Domingues, V.S., Bucciarelli, G., Almada, V.C., Bernardi, G., 2005. Historical colonization and demography of the Mediterranean damselfish, Chromis chromis. Molecular Ecology 14, 4051-4063.

Excoffier, L., Smouse, P.E., 1994. Using allele frequencies and geographic subdivision to reconstruct gene genealogies within a species. Molecular variance parsimony. Genetics 136, 343-359.

Excoffier, L., Smouse, P.E., Quattro, J., 1992. Analysis of molecular variance inferred from metric distances among DNA haplotypes: application to human mitochondrial DNA restriction data. Genetics 131, 479-491.

Excoffier, L., Laval, G., Schneider, S., 2005. Arlequin ver. 3.0: an integrated software package for population genetics data analysis. Evolutionary Bioinformatics Online 1, 47-50.

Felsenstein, J., 1985. Confidence limits on phylogenies: an approach using the bootstrap. Evolution 39, 783-791.

Fouda, M.M., Hanna, M.Y., Fouda, F.M., 1993. Reproductive biology of a Red Sea goby, Silhouettea aegyptia, and a Mediterranean goby, Pomatoschistus marmoratus, in Lake Timsah, Suez Canal. Journal of Fish Biology 43, 139-151.

Fu, Y.X., 1997. Statistical tests of neutrality of mutations against population growth and background selection. Genetics 147, 915-925.

Giovannotti, M., La Mesa, M., Caputo, V., 2009. Life style and genetic variation in teleosts: the case of pelagic (Aphia minuta) and benthic (Gobius niger) gobies (Perciformes: Gobiidae). Marine Biology 156, 239-252.

Grant, W.S., 2005. A second look at mitochondrial DNA variability in European anchovy (Engraulis encrasicolus): assessing models of population structure and the Black Sea isolation hypothesis. Genetica 125, 293-309.

Grant, W.S., Bowen, B.W., 1998. Shallow population histories in deep evolutionary lineages of marine fishes: insights from sardines and anchovies and lessons for conservation. Journal of Heredity 89 (5), 415-426.

Grant, W.S., Leslie, R.W., Bowen, B.W., 2005. Molecular genetic assessment of bipolarity in the anchovy genus Engraulis. Journal of Fish Biology 67, 12421265.

Guarniero, I., Franzellitti, S., Ungaro, N., Tommasini, S., Piccinetti, C., Tinti, F., 2002. Control region haplotype variation in the central Mediterranean common sole indicates geographical isolation and population structuring in Italian stocks. Journal of Fish Biology 60 (6), 1459-1474.

Gysels, E.S., Hellemans, B., Patarnello, T., Volckaert, F.A.M., 2004. Current and historic gene Xow of the sand goby Pomatoschistus minutus on the European continental Shelf and in the Mediterranean Sea. Biological Journal of the Linnaean Society of London 83, 561-576.

Hall, T.A., 1999. BioEdit: a user-friendly biological sequence alignment editor and analysis program for Windows 95/98/NT. Nucleic Acids Symposium Series 41, 95-98.

Hamad, N., Millot, C., Taupier-Letage, I., 2006. The surface circulation in the eastern basin of the Mediterranean Sea. Scientia Marina 70 (3), 457-503.

Harpending, H., 1994. Signature of ancient population growth in a low-resolution mitochondrial DNA mismatch distribution. Human Biology 66, 591-600.

Hudson, R.R., Boos, D.D., Kaplan, N.L., 1992. A statistical test for detecting geographic subdivision. Molecular Biology and Evolution 9 (1), 138-151.

Huelsenbeck, J.P., Rannala, B., 1997. Phylogenetic methods come of age: testing hypotheses in an evolutionary context. Science 276, 227-232.

Huson, H.D., Byant, D., 2006. Application of phylogenetic networks in evolutionary studies. Molecular Biology and Evolution 23 (2), 254-267.

Huyse, T., Houdt, J.V., Volckaert, F.A.M., 2004. Paleoclimatic history and vicariant speciation in the "sand goby" group (Gobiidae, Teleostei). Molecular Phylogenetics and Evolution 32, 324-336.

Koutrakis, E.T., Kokkinakis, A.A., Eleftheriadis, E.A., Argyropoulou, M.D., 2000 Seasonal changes in distribution and abundance of the fish fauna in the two estuarine systems of Strymonikos Gulf (Macedonia, Greece). Belgian Journal of Zoology 130 (Suppl.), 41-48.

Kristoffersen, J.B., Magoulas, A., 2008. Population structure of anchovy Engraulis encrasicolus L. in the Mediterranean Sea inferred from multiple methods. Fisheries Research 91, 187-195.

Lambeck, K., Esat, T.M., Potter, E.K., 2002. Links between climate and sea levels for the past three million years. Nature 419, 199-206.

Lemaire, C., Versini, J.J., Bonhomme, F., 2005. Maintenance of genetic differentiation across a transition zone in the sea: discordance between nuclear and cytoplasmic markers. Journal of Evolutionary Biology 18, 70-80.

Maggio, T., Lo Brutto, S., Garoia, F., Tinti, F., Arculeo, M., 2009. Microsatellite analysis of red mullet Mullus barbatus (Perciformes, Mullidae) reveals the isolation of the Adriatic Basin in the Mediterranean Sea. ICES Journal of Marine Science 66 (9), 1883-1891.

Magoulas, A., Tsimenides, N., Zouros, E., 1996. Mitochondrial DNA phylogeny and the reconstruction of population history of a species: the case of the European anchovy (Engraulis encrasicolus). Molecular Biology and Evolution 13, 178-190.

Magoulas, A., Castilho, R., Caetano, S., Marcato, S., Patarnello, T., 2006. Mitochondrial DNA reveals a mosaic pattern of phylogeographical structure in Atlantic and Mediterranean populations of anchovy (Engraulis encrasicolus). Molecular Phylogenetics and Evolution 39, 734-746.

Malavasi, S., Fiorin, R., Franco, A., Franzoi, P., Granzotto, A., Riccato, F., Mainardi, D. 2004. Fish assemblages of Venice Lagoon shallow waters: an analysis based on species, families and functional guilds. Journal of Marine Systems 51, 19-31.

Mazzoldi, C., Rasotto, M.B., 2001. Extended breeding season in the marbled goby, Pomatoschistus marmoratus (Teleostei: Gobiidae), in the Venetian lagoon. Environmental Biology of Fishes 61, 175-183.

Mazzoldi, C., Poltronieri, C., Rasotto, M.B., 2002. Egg size variability and mating system in the marbled goby Pomatoschistus marmoratus (Pisces: Gobiidae). Marine Ecology Progress Series 233, 231-239.

Mejri, R., Lo Brutto, S., Ben Hassine, O.K., Arculeo, M., 2009. A study on Pomatoschistus tortonesei Miller 1968 (Perciformes, Gobiidae) reveals the Siculo-Tunisian Strait (STS) as a breakpoint to gene flow in the Mediterranean basin. Molecular Phylogenetics and Evolution 53, 596-601.

Miglietta, M.P., Lessios, H.A., 2009. A silent invasion. Biological Invasions 11, 825834.

Miller, P.J., 1984. The tokology of gobioid fishes. In: Potts, G.W., Wootton, J.R. (Eds.), Fish Reproduction: Strategies and Tactics. Academic Press, London, pp. 119153.

Miller, J.P., 1986. The Family of Gobiidae. In: Whitehead, P.J.P., Bauchot, M.L., Hureau, J.C., Nielson, J., Tortonese, E. (Eds.), Fishes of the North Eastern Atlantic and of the Mediterranean, UNESCO, Paris, pp. 1019-1085.

Miller, J.P., Serventi, M., Soregaroli, D., Torricelli, P., Gandolfi, G., 1994. Isozyme genetics and the phylogeny of Italian freshwater gobies (Teleostei: Gobioidei). Journal of Fish Biology 44, 439-451.

Natoli, A., Birkun, A., Aguilar, A., Lopez, A., Hoelzel, A.R., 2005. Habitat structure and the dispersal of male and female bottlenose dolphins (Tursiops truncatus). Proceeding of the Royal Society B 272, 1217-1226.

Nikula, R., Väinölä,, R., 2003. Phylogeography of Cerastoderma glaucum (Bivalvia: Cardiidae) across Europe: a major break in the Eastern Mediterranean. Marine Biology 143, 339-350.

Palumbi, S.R., 1996. Nucleic acids II: the polymerase chain reaction. In: Hillis, D.M., Moritz, C., Mable, B.K. (Eds.), Molecular Systematics. Sinauer Associates, Inc., Sunderland, pp. 205-248.

Patarnello, T., Volckaert, A.M.J.F., Castilho, R., 2007. Pillars of Hercules: is the Atlantic-Mediterranean transition a phylogeographical break? Molecular Ecology 16, 4426-4444.

Penzo, E., Gandolfi, G., Bargelloni, L., Colombo, L., Patarnello, T., 1998. Messinian salinity crisis and the origin of freshwater lifestyle in Western Mediterranean gobies. Molecular Biology and Evolution 15, 1472-1480. 
Pérez-Losada, M., Mark, J.N., Crandall, K.A., Shaw, P.W., 2007. Testing hypotheses of population structuring in the Northeast Atlantic Ocean and Mediterranean Sea using the common cuttlefish Sepia officinalis. Molecular Ecology 16, 2667-2679.

Posada, D., 2008. JModelTest: phylogenetic model averaging. Molecular Biology and Evolution 25, 1253-1256.

Quignard, J.P., 1978. La Méditerranée: creuset ichtyologique. Bolletino di Zoologia $45,23-26$.

Ramos-Onsins, S.E., Rozas, J., 2002. Statistical properties of new neutrality tests against population growth. Molecular Biology and Evolution 19, 2092-2100.

Riccioni, G., Landi, M., Ferrara, G., Milano, I., Cariani, A., Zane, L., Sella, M., Barbujani, G., Tinti, F., 2010. Spatio-temporal population structuring and genetic diversity retention in depleted Atlantic Bluefin tuna of the Mediterranean Sea. PNAS 107 (5), 2102-2107.

Rigal, F., Chevalier, T., Lorin-Nebel, C., Charmantier, G., Jean-Antoine Tomasini, J.A., Aujoulat, F., Berrebi, P., 2008. Osmoregulation as a potential factor for the differential distribution of two cryptic gobiid species, Pomatoschistus microps and P. marmoratus in French Mediterranean lagoons. Scientia Marina 72 (3), 469-476.

Rogers, A.R., 1995. Genetic evidence for a Pleistocene population growth. Evolution 49, 608-615.

Rogers, A.R., Harpending, H., 1992. Population growth makes waves in the distribution of pairwise genetic differences. Molecular Biology and Evolution 9 (3), 552-569.

Rolland, J.L., Bonhomme, F., Lagardère, F., Hassan, M., Guinand, B., 2007. Population structure of the common sole (Solea solea) in the Northeastern Atlantic and the Mediterranean Sea: revisiting the divide with EPIC markers. Marine Biology 151, 327-341.

Roucek, J.S., 1953. The Geopolitics of the Mediterranean, II. American Journal of Economics and Sociology 13 (1), 71-86.

Rozas, J., Sánchez-Delbarrio, J.C., Messeguer, X., Rozas, R., 2003. DnaSP, DNA polymorphism analyses by the coalescent and other methods. Bioinformatics 19, 2496-2497.

Sarà, G., 2009. Variation of suspended and sedimentary organic matter with depth in shallow coastal waters. Wetlands 29, 1234-1242.

Sirna-Terranova, M., Lo Brutto, S., Arculeo, M., Mitton, B.J., 2006. Population structure of Brachidontes pharaonis (P. Fisher, 1870) (Bivalvia, Mytilidae) in the Mediterranean Sea, and evolution of a novel mtDNA polymorphism. Marine Biology 150, 89-101.

Slatkin, M., 1985. Gene flow in natural populations. Annual Review of Ecology and Systematics $16,393-430$.

Slatkin, M., Hudson, R.R., 1991. Pairwise comparisons of mitochondrial DNA sequences in stable and exponentially growing populations. Genetics 129, $555-562$.
Stefanni, S., Thorley, J.S., 2003. Mitochondrial DNA phylogeography reveals the existence of an evolutionarily significant unit of the sand goby Pomatoschistus minutus in the Adriatic (Eastern Mediterranean). Molecular Phylogenetics and Evolution 28, 601-609.

Stöck, M., Sicilia, A., Belfiore, N.M., Buckley, D., Lo Brutto, S., Lo Valvo, M., Arculeo, M., 2008. Post-Messinian evolutionary relationships across the Sicilian channel: mitochondrial and nuclear markers link a new green toad from Sicily to African relatives. BMC Evolutionary Biology 8, 56 .

Swofford, D.L., 2002. PAUP*. Phylogenetic Analysis Using Parsimony (*and Other Methods). Version 4. Sinauer Associates Inc., Sunderland, MA.

Tajima, F., 1989. Statistical methods to test for nucleotide mutation hypothesis by DNA polymorphism. Genetics $123,585-595$

Thompson, J.D., Higgins, D.G., Gibson, T.J., 1994. CLUSTAL W: improving the sensitivity of progressive multiple sequence alignment through sequence weighting, positions-specific gap penalties and weight matrix choice. Nucleic Acids Research 22, 4673-4680.

Verdiell-Cubedo, D., Oliva-Paterna, F.J., Torralva, M., 2007. The effects of competitors on fitness of marbled goby Pomatoschistus marmoratus (Pisces: Gobiidae) in the Mar Menor coastal lagoon (SE Iberian Peninsula). Italian Journal of Zoology 74 (2), 169-177.

Wallis, G.P., Beardmore, J.A., 1984a. An electrophoretic study of the systematic relationships of some closely related goby species (Pisces, Gobiidae). Biological Journal of the Linnean Society 22, 107-123.

Wallis, G.P., Beardmore, J.A., 1984b. Genetic variation and environmental heterogeneity in some closely related goby species. Genetica 62, 223-237.

Ward, R.D., Zemlak, T.S., Innes, B.H., Last, P.R., Hebert, P.D.N., 2005. DNA barcoding Australia's fish species. Philosophical Transactions of the Royal Society of London. Series B, Biological Sciences 360, 1847-1857.

Zardoya, R., Castilho, R., Grande, C., Favre-Krey, L., Caetano, S., Marcato, S., Krey, G., Patarnello, T., 2004. Differential population structuring of two closely related fish species, the mackerel (Scomber scombrus) and the chub mackerel (Scomber japonicus), in the Mediterranean Sea. Molecular Ecology 13, 17851798.

Zitari-Chatti, R., Chatti, N., Fulgione, D., Caiazza, I., Aprea, G., Elouaer, A., Said, K., Capriglione, T., 2009. Mitochondrial DNA variation in the caramote prawn Penaeus (Melicertus) kerathurus across a transition zone in the Mediterranean Sea. Genetica 136, 439-447.

Zulliger, D.E., Tanner, S., Ruch, M., Ribi, G., 2009. Genetic structure of the high dispersal Atlanto-Mediterreanean sea star Astropecten aranciacus revealed by mitochondrial DNA sequences and microsatellite loci. Marine Biology 156, 597610. 